TAPROBANICA, ISSN 1800-427X. April, 2011. Vol. 03, No. 01: pp. 18-30.

(C) Taprobanica Private Limited, Jl. Kuricang 18 Gd.9 No.47, Ciputat 15412, Tangerang, Indonesia.

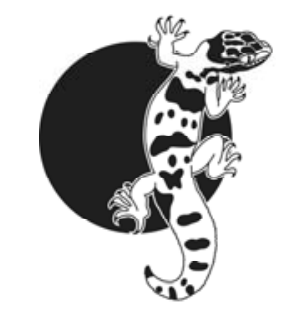

\title{
BENTHIC MACRO-INVERTEBRATE FAUNA AND "MARINE ELEMENTS" SENSU ANNANDALE (1922) HIGHLIGHT THE VALUABLE DOLPHIN HABITAT OF RIVER GANGA IN BIHAR - INDIA
}

\author{
Hasko Nesemann ${ }^{1}$, Gopal Sharma ${ }^{2}$ and Ravindra K. Sinha ${ }^{1}$
}

\footnotetext{
${ }^{1}$ Centre for Environmental Science, Central University of Bihar, BIT Campus, Patna-800 014, India

${ }^{2}$ Zoological Survey of India, Gangetic Plains Regional Centre, Road No. 11-D, Rajendra Nagar, Patna-800 016, India E-mail: gprszsipatna@rediffmail.com
}

\begin{abstract}
From the main channel of River Ganga 95 invertebrate taxa have been recorded in the endangered Gangetic Dolphin (Platanista gangetica) habitat over an observation period of ten years. Mollusks, Annelids and Arthropods are the dominating benthic groups that constitute the detritivores, filter-feeders and sediment feeders, scrapers/grazers and herbivores. The benthic sediment fauna is rich in diversity and high in abundance. This enables carnivores to occupy a large variety of specialized ecological niches. The qualitative faunal composition of Ganga resembles in general large European rivers with similar representation of taxa. Twelve taxa of marine-originated families were identified, but none of them can be classified as invasive or non-indigenous species. Only two taxa are certainly recognized as non-indigenous neozoans, whereas the remaining fauna shows pristine and stable ecological conditions. In this aspect River Ganga differs from regulated large rivers, where faunal change has largely replaced the original species inventory. Despite the heavy pollution in parts of the river, the original composition of biological diversity is still persisting in the middle reaches of the Ganga. This provides hope for the survival of the Gangetic Dolphin.
\end{abstract}

Key words: Aquatic, invasive species, functional feeding groups, Gangetic Dolphin

\section{Introduction}

The Ganga is the largest river among the rivers originating from the Himalayan region in northern India. The river section in Bihar is one of the few natural and free-flowing large rivers in south Asia.
It is a water resource for one of the world's most fertile plains with pristine river morphology. This river is an irreplaceable unique habitat for the endangered Gangetic dolphin, Platanista gangetica 
gangetica (Roxburgh 1801) and many other endemic and endangered species.

The benthic fauna studied included all groups of taxonomic units to provide comparable results regarding diversity of different habitat-types. Reference data were available for several invertebrate groups only through Datta Munshi et al. (1988), Sharan \& Sinha (1988), Sinha (1988) and Subba Rao (1989) from the localities near Patna. Systematic investigations have been conducted for several gastropods e.g. Stenothyridae and Physidae (Sinha \& Sharma 2001; Sinha et al., 2003), bivalves (Nesemann et al., 2003, Nesemann et al., 2005) and Annelids (Nesemann et al., 2004).

Although throughout most of its range the Gangetic dolphin is declining because of river developments, pollution, deliberate killing and entanglement in nets (Smith and Braulik, 2008) all along the study area there is a good habitat. Five to ten dolphins were regularly surfacing a few meters away from the sampling sites in the main current. Altogether up to 37 dolphins inhabit the River Ganga stretch around Patna (Sinha et al., 2010).

\section{Materials and Methods}

The macro-invertebrate fauna of the Ganga River was investigated frequently along the right bank in the city of Patna. Benthic samples were collected qualitatively using a hand net. Annelid specimens were preserved in $70 \%$ ethanol; leeches were usually relaxed in $15 \%$ ethanol, and then transferred into $70 \%$ ethanol for preservation. Molluscs and decapods were washed from the sediment samples at the spot and if necessary preserved in $4 \%$ formaldehyde. Usually only empty shells of large bivalves have been collected and living specimens were released.

Study area: The main study area is the right (erosion-) bank of a $4 \mathrm{~km}$ stretch of River Ganga along the city of Patna from Mahendrughat in the west ( $\left.25^{\circ} 37^{\prime} 19^{\prime \prime} \mathrm{N}, 85^{\circ} 09^{\prime} 18^{\prime \prime} \mathrm{E}\right)$ downstream to Bhadraghat in the East $\left(25^{\circ} 36^{\prime} 40^{\prime \prime} \mathrm{N}, 85^{\circ} 12^{\prime} 35^{\prime \prime}\right.$ E). The faunal collection were done from Mahendrughat, seeping springs, Mahendrughat downstream, Adalatghat, Periphyton, Krishnaghat upstream, Gandhighat, Old Palace, Lithal, artificial stone substrate, Old Palace, Phytal: Potamogeton crispus.

The research was conducted from $31^{\text {st }}$ January 2000 to $31^{\text {st }}$ January 2011 including frequent field observations. Altogether eight sites have been visited frequently and their exact results are shown in table 1-3. In addition the left (sedimentation-) bank opposite city of Patna was visited between October and March for collecting faunal samples from different habitats (Boulders, sand, silt and mud substrate).

\section{Results}

The benthic macro-invertebrate fauna of the main channel comprises 95 identified taxa with high diversity of 26 species of annelids (Table 1), 35 species of mollusks (Table 2) and 29 families, genera or species of arthropods (Table 3), The higher crustacean (Malacostraca) fauna includes 8 taxa of crabs, prawns, shrimps, mysid shrimps and one isopod. Aquatic insects are mainly represented with 21 identified taxa out of which nymphs of Dragonflies and Damselflies, larvae of Two-winged flies and adults of Water-Bugs are the most striking groups. Additionally the presence of Roundworms (Nematoda) and Ribbon worms (Nemertina) was generally noticed with small abundances.

Functional Feeding Groups of Macroinvertebrates in the River Ganga: The habitat was classified according to longitudinal and lateral terminology described and defined by Illies (1961), Illies \& Botosaneanu (1963) and Amoros \& Roux (1988). The River Ganga at Patna is a heterotrophic Meta-Potamon system. Organic load is brought from upstream through river-continuum or it is introduced from surroundings along the banks and during flood. According to the commonly used classification of higher invertebrate taxa and field observations, their particular role in processing food can be roughly outlined at least at family level. Each taxon is assigned to a specific functional feeding group based on the definitions of Vannote et al. (1980), Williams \& Feltmate (1992), Merritt \& Cummins (1996). Functional feeding groups at family level (Tables 1-3) are summarized and figured for 51 taxa found in River Ganga at Patna, based on the qualitative composition of benthic fauna (Fig. 1).

The detritivores include in part shredders (Polychaeta) and scrapers or grazers (Gastropoda) with all sediment- and filter feeders. Altogether 54 $\%$ of the families can be assigned to this group (Fig. 2 ). The true carnivores represent $34 \%$ of the qualitative faunal composition, indicating high diversification and prey specialization (Fig. 3). Herbivores (minimum of $2 \%$ or more) are the minor group in the turbid River Ganga, and this may well reflect the rare occurrence of vascular 
aquatic plants along the banks. Some scrapers among the gastropods, especially Lymnaeidae, and miners among the insects e.g. Pyralidae nymphs of moths feed mainly on living algae and macrophytes.

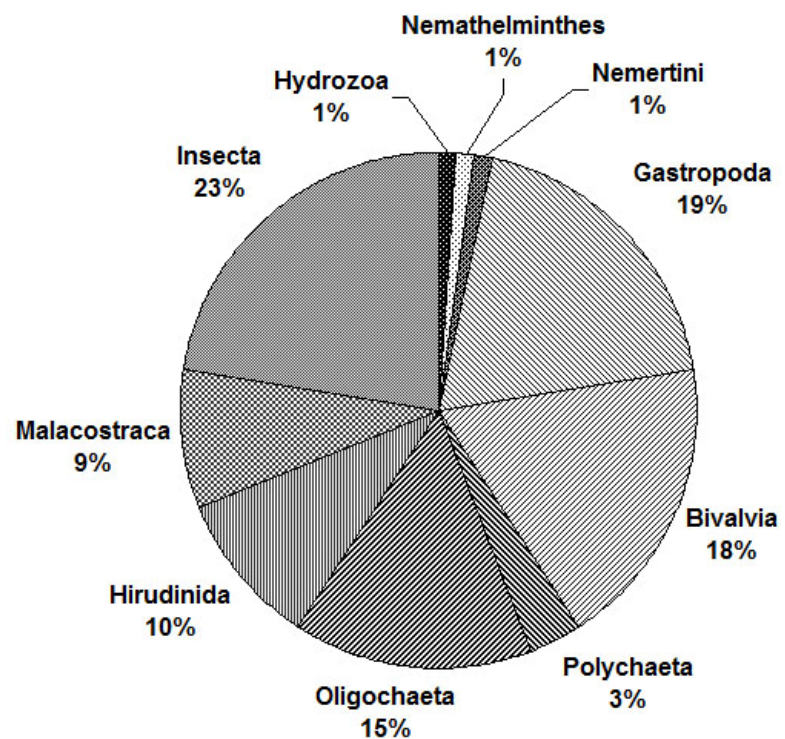

Figure 1: Qualitative composition of Benthic MacroInvertebrates of the River Ganga at Patna with 95 identified taxa.

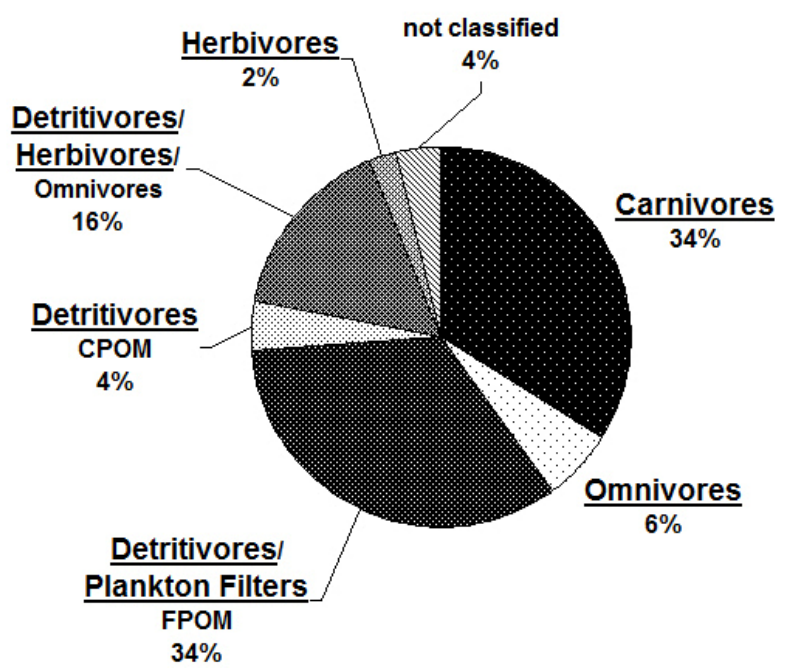

Figure 2: General Feeding Guilds of Benthic MacroInvertebrates in River Ganga with 51 classified families of the present study: Dominance of Detritivores (54\%), Herbivores and others (12\%) over Carnivores (34\%).

The “Marine Element" (Annandale 1922): Besides the Gangetic River dolphin Platanista gangetica gangetica, some unique freshwater species of predominantly or nearly exclusively marine invertebrate families have drawn early attention of scientists. Annandale (1922) has already distinguished two groups of marine origin characterizing these as "The Euryhaline Fauna of the Delta" and "The Relict Fauna of the River". He listed three bivalves Novaculina gangetica, Scaphula celox and Scaphula deltae as relict fauna. Their occurrence in River Ganga nowadays extends upstream to $1500 \mathrm{~km}$ away from coastal waters and the Gangetic delta region. According to Annandale (1922) they are possible marine relics of the former tertiary sea.

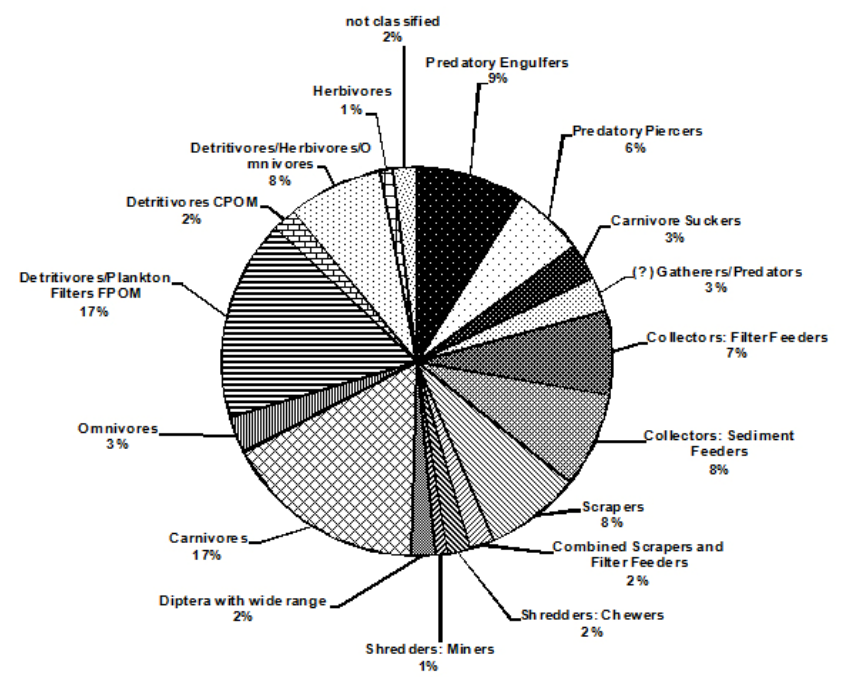

Figure 3: Functional Feeding Groups of Benthic Macroinvertebrates in River Ganga with 51 classified families of the present study.

Presently a total of twelve species of the macroinvertebrates occur at Patna belonging to marineoriginated or primary brackish water families. These are Nereididae: Namalycastis indica, Nephthydae: Nephthys oligobranchia, Ozobranchidae: Ozobranchus shipleyi, Stenothyridae: Stenothyra ornata, Gangetia miliacea, Arcidae: Scaphula celox, S. deltae, Psammobiidae: Novaculina gangetica, Mysidae: Gangemysis assimilis, Corallanidae: Tachaea spongillicola, and Hymenosomatidae: Hymenicoides carteri, Neorhynchoplax spp.

Recent observations of invertebrate invasion along large rivers used as waterways allow two alternative hypotheses:

1. The occurrence of the above-mentioned species in freshwater upstream from the upper tidal limit are true marine "Relict fauna of the River Ganges" according to Annandale (1922).

2. The occurrence of the above mentioned species in freshwater upstream from the upper tidal limit is based on both recent introduction by shipping and ongoing upstream range extension by active dispersal as a response to the increasing human impact with environmental changes of habitat. 
Since the species are restricted to the Ganges River, their presence may be due to the use of the waterway during the last one hundred years. On other hand, some species of "marine origin" are widespread throughout the Gangetic plain. Here the artificial introduction by shipping is most unlikely. All species are native to the Indian subcontinent, eleven of them being originally described from the delta region of River Ganges with type localities somewhere in Hugli River floodplain or connected channels. Two examples will be described here in detail with data of their first collections (Nesemann et al., 2007) and additional records (Nesemann 2009):

\section{Tachaea spongillicola (Stebbing 1907)}

Material examined: Nepal, Rupandehi District, Ghagara Khola, February 1994, leg. S. Sharma \& H. Nesemann; Nepal, Rautahat District, Lamaha Khola at Shivpur, February 1994, leg. S. Sharma \& H. Nesemann, October 2005, leg. Sharma, Tachamo, Shah, Nesemann; Nepal, Rautahat District, Jhajh Nadi confluence into Bagmati River, October 2005, May 2006, leg. Timalsina, Tachamo, Shah, Nesemann; Nepal, Kailali District, Jagadishpur reservoir, January 2008, leg. Tachamo, Shah, Nesemann; Nepal, Sunsari District, Khantaha River at Kushaha and Haripur, December 1996, leg. S. Sharma, S. Khanal \& H. Nesemann; India, Bihar, Ganga River right bank at Patna, Old Palace, March 2003, leg. H. Nesemann; India, Bihar, Pupun River at Fatuha, November 2002, leg. G. Sharma \& H. Nesemann; India, Bihar, Ganga River right bank upstream from Buxar, April 2004, leg. D. Kedia, G. Sharma \& H. Nesemann.

This isopod has been originally described by Stebbing (1907) from a freshwater tank at Kolkata as a commensal of the freshwater sponge Spongilla carteri. The first record of $T$. spongillicola being collected as ectoparasites of freshwater prawns Macrobrachium spp. in southern India was published by Mariappan, Balasundaram \& Trilles (2003). During the present survey T. spongillicola was regularly collected from benthic samples of lowland streams and small rivers of the Lower Gangetic Plain in Nepal and India as well as from River Ganges itself. The wide distribution range exceeds northwards to the Himalayan foothill streams in the Terai region. This may indicate the natural pattern of dispersal.

\section{Gangemysis assimilis (Tattersall, 1908)}

Material examined: Nepal, Rautahat District, Barahwa Nadi north of Gaur, December 2005, May
2006, leg. Sharma, Timalsina, Tachamo, Shah, Nesemann; Nepal, Rautahat District, Jhajh Nadi confluence into Bagmati River, December 2005, May 2006, leg. Sharma, Timalsina, Tachamo, Shah, Nesemann; Nepal, Rautahat District, Jhajh Nadi confluence into Bagmati River, December 2005, May 2006, leg. Timalsina, Tachamo, Shah, Nesemann; India, Bihar, Ganga River right bank at Patna, Old Palace, March 2003, leg. H. Nesemann; India, Bihar, Ganga River at Patna, Adalatghat, March 2008, leg. G. Sharma \& H. Nesemann.

This mysid shrimp has been originally described by Tattersall (1908) from a brackish water pond at Port Canning. The first records of G. assimilis were collected in small rivers and oxbow lakes of southern Nepal from December 2005 onwards (Nesemann et al., 2007). During the present survey G. assimilis was collected from periphyton-samples from River Ganges itself in March 2008. The wide distribution range northwards to the Himalayan foothill streams in the Terai region resembles the distribution pattern of the isopod T. spongillicola. It supports the natural pattern of dispersal of this species.

\section{Discussion}

How to identify invasive species (Neozoa) among benthic Macro-invertebrates in the River Ganga? Neozoa are numerously reported among the aquatic invertebrates of many large rivers all over the northern hemisphere. The neozoa are benefited from regulated rivers and ships often initially distribute them. The total amount of non-indigenous macro-invertebrates in rivers can be used to understand and describe the degree of anthropogenic changes of the potamocoenosis environment. Many neozoa tolerate higher salinity as well and originate from costal brackish waters. Therefore several neozoa (e.g. the Danubian Limnomysis benedeni Czerniavsky, 1882 of the ponto-caspian basin) have been erroneously regarded as marine relicts. This question is of great interest for the River Ganga fauna. It makes it necessary to review thoroughly the following four aspects for each species:

1. How long back does the knowledge of any particular species dates?

2. From which country and watershed the species has been described?

3. Is there any certain observation of the invasive character of the species?

4. Does the analysis of the present-day distribution pattern allow any conclusions about the probable impact of transportation by waterways? 
Many taxa of River Ganga that could be identified to species level are most likely a part of the indigenous fauna; based on the knowledge from their first observations. They could have been originally described from either northern Indian subcontinent or from Gangetic delta and certain literature records are known from nineteenth or early twentieth century. For some popular gastropods, the River Ganga is representing the "terra typica" without any precise location e.g. Brotia costula. Early observations of numerous aquatic molluscs have been already mentioned from Gangetic plains by Preston (1915) and Annandale (1922) and additional records were summarized by Subba Rao (1989). Several malacostracans (Mysida, Decapoda) have been originally described from Gangetic delta in Bengal. Similarly some of the wide spread oriental leeches have been already reported from at least few localities of Gangetic Plains by Harding \& Moore (1927). Thus the presumed theory of recent faunal changes in River Ganga by invasion or introduction of euryhaline and pollution-tolerant neozoa is not supported with any certain observations. In contrast it has to be highlighted that all members of marine-originated families are autochthonous species of the river since their scientific discovery and description.

Among all invertebrates found in the study area at Patna only two species can be certainly identified as non-native invaders, so-called neozoa (Fig. 1). The gastropod Haitia mexicana is of nearctic origin with rapid spreading during last fifteen years. This North American Physidae Haitia mexicana was invading the river system since the early nineties, starting from few introductions in 1994 in capitals like New Delhi and Kathmandu and in 1998 in Allahabad. Its rapid spreading was initiated by commercial distribution of aquaria material and aquatic plants. Shortly after colonization of River Ganga in Patna after 1998, H. mexicana was found in high abundance. Since that time the individual density is declining. Mass occurrence is nowadays restricted to few highly polluted places, where $H$. mexicana lives without competition with other gastropods (Sinha et al., 2003).

The earthworm Perionyx excavatus originates from the Eastern Himalayan foothills (Gates, 1972). This species is helpful in agriculture, with successful early introductions to subtropical countries all over the world. Many pan-tropical localities have been already reported by Gates (1972) from the first half of twentieth century. In Gangetic Plain P. excavatus appears to be well established since long. Thus the occurrence in semi-aquatic zone of River Ganga at Patna might be the result of natural invasion from agricultural terrestrial habitats.

\section{Comparison of River Ganga fauna (Oriental} region) with large rivers of temperate Central Europe (Palearctic region): Although numerous faunal lists and inventories have been published for floodplains of large rivers (Obrdlik, Falkner \& Castella 1995), detailed studies on the benthic invertebrates of main channels are very rare. Important reason is the different quality of taxa-lists caused by incomparable intensity of research and different levels of identification. Thus only a few studies of large rivers can be compared with the present results of River Ganga. The current identification level for microdrile tube worms (Oligochaeta: Tubificina) and aquatic insects, especially dipterans, varies largely in different studies and it needs a detailed comparison for each individual river.

The Gangetic fauna of Patna is compared with some of the largest European rivers Rhine, Main and Oder flowing into the North and Baltic Seas for discussion of differences in Potamocoenosis of Eurasian subtropical and temperate zones. Comparable faunal lists of representative river sections in low altitudes and plains have been rarely published for all macro-zoo benthic organisms. The results investigated by Kinzelbach (1983, 1985), Sopp (1983), Ziese (1985, 1987), Schmid (1999) and Schleuter \& Haybach (2003) provide benthic faunal particulars of the main river channels (Table 4). The available physico-chemical parameters show similar condition in the lowland rivers except of the temperature range.

In biodiversity all large rivers have three main components of benthic macro-invertebrates: Mollusca (Class: Bivalvia, Gastropda), Arthropoda (Class: Malacostraca, Insecta) and Annelida. Molluscs are more diversified and most dominating in River Ganga with $38 \%$ of identified taxa. The temperate aquatic malacofauna ranges from $21-28$ $\%$. Arthropods are leading groups in Rhein (Rhine), Main and Oder Rivers with $33-51 \%$, but identification level cannot be compared directly due to different species-, genus- and family-level. In contrast the Gangetic insects $(23 \%)$ are insufficiently known from the preliminary list at family level. In Annelids all three major groups (Polychaeta, Oligochaeta, Hirudinida) cover $28 \%$ of the identified taxa in River Ganga and the fauna has been carefully investigated and described. The 
European rivers display similar amount of annelid taxa with $30 \%$ for Order, largely based on the very rich Tubificidae diversity, up to $19 \%$ for Rhine and $17 \%$ for Main River. It is noteworthy that the true freshwater Polychaeta were originally absent in the river systems of North and Baltic Sea.

Neozoa in River Ganga compared with the European Rivers (Fig. 4): In regulated large rivers of temperate zone the indigenous or native benthic invertebrates are becoming accompanied by aquatic invaders or invasive species. They are partially replacing the reduced original fauna or even occupy free ecological niches. Neozoa play an important role in benthic fauna of navigable rivers. Their increasing number of species is sufficiently documented in some European rivers and especially studied for River Rhine (Fig. 4). The relative amount of non-indigenous invasive species changes from estimated $2-6 \%$ to approximately $12-18 \%$ of the total number of identified taxa within the last hundred years (Kinzelbach 1983, Nehring 2003). Similar tendency in Rivers Main (21 Neozoa) and Oder (14 Neozoa) is showing the same range.

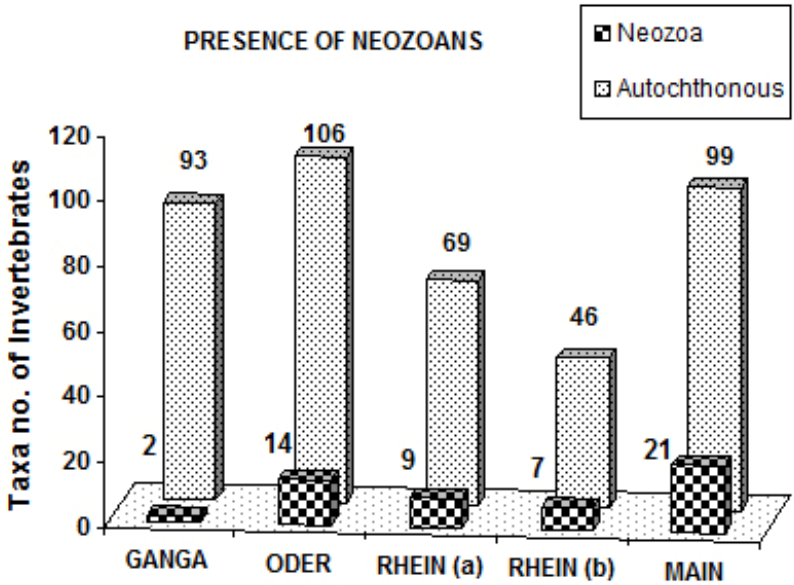

Figure 4: Presence of Neozoa in River Ganga main channel in comparison with lowland-reaches of large river systems (main channels) in Central Europe, Germany.

\section{Discussion of possible reasons for faunal changes} in River Ganga: Natural changes are well documented and redrawn from satellite photographs. The river bed permanently undergoes a high natural dynamic process. During the last decade the lateral erosion has shifted the main channel of River Ganga bed northwards. The river became diverted upstream Patna city and the location of the confluence of the Gandak River has changed to a northern direction. The most important visible change of environmental condition is the fact that the former main channel of River Ganga along Patna has now become a southern branch with residual flow during low water season. Consequently deposition of silt from Ganges and deposition of sand from Gandak have reduced the maximum depth and water current along the right bank of the river.

Anthropogenic changes took place along the Patna section during the same time.

1. The organic load has been reduced by sewage treatment plants as a measurable result of the Ganga Action Plan.

2. The bank fixation originally constructed by standardized bricks was renewed and enlarged with large amount of natural boulders $(>30 \mathrm{~cm})$ along the water's edge for low water level.

Thus substrate compositions of the right bank are gradually changed. Loam and silt have been reduced or covered and replaced by hard substrate. The quality of hard substrate in form of large natural boulders is providing stable surface habitat for lithophilic species, especially leeches (Hirudinida) and snails (Gastropoda) largely supported by the interspaces and subsurface. These artificially created micro-habitats are stable against flood-disturbance during monsoon period.

Lotic/rheophilic species are declining (Novaculina gangetica, Namalycastis indica, Hymenosomatidae), whereas lentic fauna is more supported by the residual flow with side-arm condition during low water period. Especially the increasing density and extension of large freshwater mussels is co related with the environmental changes. Dense mussel-beds were observed in May 2010 at Gandhighat, where ten years ago in January 2000 mostly Thiara scabra and Thiara lineata have been the dominating molluscs. Polychaetes and spider crabs disappeared at the same place.

\section{Conclusion}

Faunal change of benthic macro-invertebrates in River Ganga: Compared with initial studies (Sharan and Sinha 1988, Sinha 1988), the number of taxa is continually growing throughout the last years. In the following decades more detailed studies have been conducted and thorough sampling has brought to light the discovery of many species. On the other hand, the continuous fieldobservations have clearly documented some faunal change for several groups: 
1. Appearance of invasive non-indigenous species, which have not been recorded before 1998: Physidae: Haitia mexicana.

2. Appearance of indigenous species, which have been overlooked or miss-identified during previous studies: Examples are the Hymenosomatidae: Hymenicoides carteri, Neorhynchoplax sp., Tachaea spongillicola, Gangemysis assimilis.

3. Decline of indigenous species, which have been recorded with high abundance during previous studies: Psammobiidae: Novaculina gangetica.

4. Increase of indigenous species, which have been recorded with low abundance during previous studies: Leeches Hirudinida e.g. Alboglossiphonia sp., Salifa sp. and others.

5. Enlargement and downstream-shifting of the dense mussel-bed within the present study: Unionidae and Amblemidae: Lamellidens spp. and Radiatula spp.

The present scientific knowledge of macroinvertebrates from River Ganga before the twentieth century is very poor. It is limited mainly to collections of molluscs (Preston 1915, Annandale 1922). Many invertebrate species of marine and brackish origin were described in the early twentieth century and no exact observations prior to their scientific descriptions are available. Thus "The Relict Fauna of the River" (Annandale 1922: 146) "that flourish in the Middle Reaches of Ganges" cannot be certainly assigned to invasive, nonindigenous species. Considering the high number and native character of the marine-originated families, they can be regarded as original members of the eco-region of Lower Gangetic Plains. There is neither proof for their rapid invasion within the last decades, nor for their absence. The few studies on benthic fauna do not allow comparison of the present-day situation with former conditions one hundred years ago. While comparing River Ganga with regulated European rivers the presumed analogous faunal change is not supported. In contrast Ganges fauna has preserved comparatively semi-natural conditions with original species inventory of most invertebrates. The benthic neozoa are actually represented with $2 \%$ of total identified taxa, similar to large European rivers at the end of nineteenth century (Fig. 4). Thus the River Ganga around Patna displays a rich aquatic biodiversity, but the ecological status needs sustainable conservation and improvement of the ecosystem.

Table 1: Taxa-list for Annelida in River Ganga at Patna.

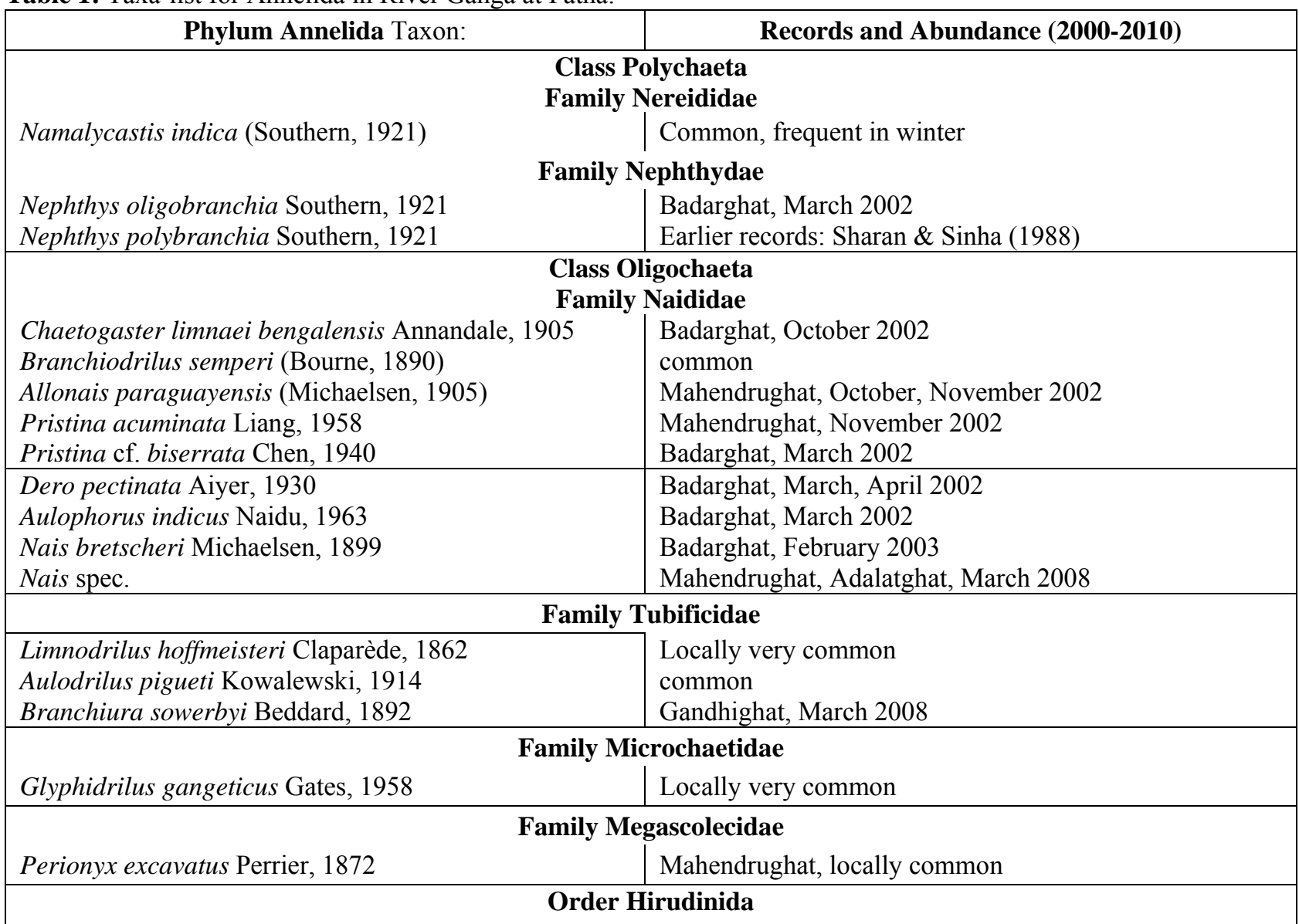




\begin{tabular}{|c|c|}
\hline \multicolumn{2}{|c|}{ Family Glossiphoniidae } \\
\hline $\begin{array}{l}\text { Alboglossiphonia weberi (Blanchard, 1896) } \\
\text { Alboglossiphonia pahariensis Nesemann \& Sharma, } \\
2007 \\
\text { Placobdelloides fulvus (Harding, 1921) }\end{array}$ & $\begin{array}{l}\text { common } \\
\text { Gandhighat, May } 2010 \\
\text { Widespread but not abundant }\end{array}$ \\
\hline \multicolumn{2}{|c|}{ Family Ozobranchidae } \\
\hline Ozobranchus shipleyi Harding, 1909 & Gandak confluence, March 2001 \\
\hline \multicolumn{2}{|c|}{ Family Hirudinidae } \\
\hline Asiaticobdella birmanica (Blanchard, 1894) & Mahendrughat, January, November 2002 \\
\hline \multicolumn{2}{|c|}{ Family Salifidae } \\
\hline $\begin{array}{l}\text { Barbronia weberi (Blanchard, 1894) } \\
\text { Salifa lateroculata (Kaburaki, 1921) } \\
\text { Salifa biharensis Nesemann, Sharma \& Sinha, } 2004 \\
\text { Odontobdella krishna Nesemann \& Sharma, } 2011\end{array}$ & $\begin{array}{l}\text { Mahendrughat, locally common } \\
\text { Widespread but not abundant } \\
\text { Mahendrughat, Gandhighat } \\
\text { Gandhighat, May } 2010\end{array}$ \\
\hline \multicolumn{2}{|c|}{ Total number of identified taxa: 26} \\
\hline
\end{tabular}

Table 2: Taxa-list for Mollusca in River Ganga at Patna.

\begin{tabular}{|c|c|}
\hline Phylum Mollusca Taxon: & Records and Abundance (2000-2010) \\
\hline \multicolumn{2}{|c|}{$\begin{array}{l}\text { Class Gastropoda } \\
\text { Family Bithyniidae }\end{array}$} \\
\hline Digoniostoma pulchella (Benson, 1836) & Old Palace, March 2008 \\
\hline \multicolumn{2}{|c|}{ Family Stenothyridae } \\
\hline $\begin{array}{l}\text { Stenothyra ornata Prashad, } 1921 \\
\text { Gangetia miliacea (Nevill, 1880) }\end{array}$ & $\begin{array}{l}\text { Gandak confluence 2001, PM Ghat } 2004 \\
\text { Old Palace, March } 2003\end{array}$ \\
\hline \multicolumn{2}{|c|}{ Family Thiaridae } \\
\hline $\begin{array}{l}\text { Thiara (Tarebia) lineata Gray, } 1828 \\
\text { Thiara (Thiara) scabra (O. F. Müller, 1774) } \\
\text { Thiara (Tarebia) granifera (Lamarck, 1822) } \\
\text { Melanoides tuberculatus (O. F. Müller, 1774) }\end{array}$ & $\begin{array}{l}\text { Very common } \\
\text { Very common } \\
\text { Rare } \\
\text { Common }\end{array}$ \\
\hline \multicolumn{2}{|c|}{ Family Pleuroceridae } \\
\hline Brotia costula costula (Rafinesque, 1833) & Common \\
\hline \multicolumn{2}{|c|}{ Family Viviparidae } \\
\hline $\begin{array}{l}\text { Bellamya (Filopaludina) bengalensis (Lamarck, 1822) } \\
\text { Mekongia crassa (Benson, 1836) (=Bellamya crassa) }\end{array}$ & $\begin{array}{l}\text { Common } \\
\text { Very common }\end{array}$ \\
\hline \multicolumn{2}{|c|}{ Family Lymnaeidae } \\
\hline Lymnaea acuminata (Lamarck, 1822) & Krishnaghat, 2003, Gandhighat, May 2010 \\
\hline Radix persica (Issel, 1865) & Common \\
\hline \multicolumn{2}{|c|}{ Family Planorbidae } \\
\hline $\begin{array}{l}\text { Ferrissia verruca (Benson, 1855) } \\
\text { Ferrissia baconi (Bourguignat, 1853) } \\
\text { Indoplanorbis exustus (Deshayes, 1834) } \\
\text { Gyraulus convexiusculus (Hutton, 1849) }\end{array}$ & $\begin{array}{l}\text { Rare } \\
\text { Krishnaghat, } 2002 \\
\text { Rare } \\
\text { Rare }\end{array}$ \\
\hline \multicolumn{2}{|c|}{ Family Physidae } \\
\hline Haitia mexicana (Phillipi, 1889) & Common \\
\hline \multicolumn{2}{|c|}{ Family Succineidae } \\
\hline Quickia bensoni (Pfeiffer) & Common: Mahendrughat \\
\hline $\begin{array}{r}\text { Class Bival } \\
\text { Fam }\end{array}$ & $\begin{array}{l}(=\text { Pelecypoda }) \\
\text { Arcidae }\end{array}$ \\
\hline
\end{tabular}


Scaphula celox Benson, 1836

Scaphula deltae Blanford, 1867
Locally abundant on hard sustrate

Rare: Mahendrughat, Old Palace

\section{Family Psammobiidae}

Novaculina gangetica Benson, 1830

Silt, loam substrate (? declining population)

Corbicula striatella Deshayes, 185

Corbicula bensoni Deshayes, 1854

Corbicula assamensis Prashad, 1828

Corbicula aurea Nesemann \& Sharma, 2007

\section{Family Corbiculidae}

Common

Rare, common only at Badarghat

Rare: Mahendrughat, Badarghat

Rare: Mahendrughat, Badarghat

\section{Family Sphaeriidae}

Pisidium (Afropisidium) clarkeanum G. \& H. Nevill, 1871

Pisidium (Afropisidium) nevillianum Theobald, 1876

Rare: Gandhighat, common: Badarghat

Rare: Badarghat

Lamellidens corrianus (Lea, 1834)

Lamellidens consobrinus (Lea, 1859)

\author{
Family Unionidae \\ Very common \\ Fairly common
}

Radiatula caerulea (Lea, 1831)

Radiatula occata (Lea, 1860)

Radiatula lima (Simpson, 1900)

"Radiatula" olivaria (Lea, 1831)

Parreysia favidens chrysis (Benson, 1862)

Parreysia corrugata laevirostris (Benson, 1862)

\title{
Family Amblemidae
}

Total number of identified taxa: 35

Table 3: Taxa-list for Arthropoda (Malacostraca, Insecta) in River Ganga at Patna

\begin{tabular}{|c|c|}
\hline Phylum Crustacea Taxon: & Records and Abundance (2000-2010) \\
\hline \multicolumn{2}{|c|}{$\begin{array}{l}\text { Class Malacostraca: Order Mysida } \\
\text { Family Mysidae }\end{array}$} \\
\hline Gangemysis cf. assimilis (W.M. Tattersall, 1908) & Adalat Ghat, March 2008 \\
\hline \multicolumn{2}{|c|}{$\begin{array}{l}\text { Order Isopoda: Family Corallanidae } \\
\end{array}$} \\
\hline Tachaea spongillicola Stebbing, 1907 & Old Palace, March 2003 \\
\hline \multicolumn{2}{|c|}{ Order Decapoda: Family Palaemonidae } \\
\hline Macrobrachium spec. & Old Palace, frequently observed \\
\hline \multicolumn{2}{|c|}{ Family Atyidae } \\
\hline “Caridina” spec. & Common \\
\hline \multicolumn{2}{|c|}{ Family Hymenosomatidae } \\
\hline $\begin{array}{l}\text { Hymenicoides carteri Kemp, } 1917 \\
\text { Neorhynchoplax spec. }\end{array}$ & $\begin{array}{l}\text { Common, winter saison 2000-2003, } 2011 \\
\text { Widespread but not abundant, winter saison }\end{array}$ \\
\hline \multicolumn{2}{|c|}{ Family Parathelphusidae } \\
\hline $\begin{array}{l}\text { Barythelphusa lugubris (Wood-Mason, 1871) } \\
\text { Parathelphusa martensi (Wood-Mason, 1871) }\end{array}$ & $\begin{array}{l}\text { Locally common } \\
\text { Krishnaghat, March } 2010 \text { (Exuviae's) }\end{array}$ \\
\hline \multicolumn{2}{|c|}{$\begin{array}{l}\text { Class Insecta: Order Odonata } \\
\text { Family Gomphidae: }\end{array}$} \\
\hline $\begin{array}{l}\text { Asiagomphus spec. } \\
\text { Macrogomphus spec. }\end{array}$ & $\begin{array}{l}\text { Common, adults March-May } \\
\text { Ghajghat, January } 2011\end{array}$ \\
\hline Family Libellulidae Gen spp. & Gandhighat, May 2010 \\
\hline Family Protoneuridae Gen spp. & Old Palace, aquatic plants, March 2008 \\
\hline
\end{tabular}




\begin{tabular}{|c|c|}
\hline Family Coenagrionidae Gen spp. & Left bank opposite Patna, Macrophytes \\
\hline \multicolumn{2}{|c|}{ Order Trichoptera } \\
\hline Family Hydropsychidae Gen spp. & Very common, adults April-June \\
\hline \multicolumn{2}{|c|}{ Order Lepidoptera } \\
\hline Family Pyralidae Gen spp. & Old Palace, aquatic plants, March 2008 \\
\hline \multicolumn{2}{|c|}{ Order Diptera } \\
\hline Family Chironomidae Gen spp. & Common \\
\hline Family Ceratopogonidae Gen spp. & Gandak confluence, sand substrate \\
\hline Family Psychodidae Gen spp. & Rare: Mahendrughat, March 2008 \\
\hline Family Culicidae Gen spp. & Very common \\
\hline Family Muscidae Gen spp. & Old Palace, hard substrate \\
\hline \multicolumn{2}{|c|}{ Order Heteroptera: Family Belostomatidae } \\
\hline Diplonychus annulatus ( Fabricius, 1781) & Old Palace, aquatic plants, March 2008 \\
\hline $\begin{array}{c}\text { Family Nepidae: Nepinae: Laccotrephes spec. } \\
\text { Ranatrinae: Ranatra spec. }\end{array}$ & $\begin{array}{l}\text { Old Palace, March 2008, Gandhighat, May } 2010 \\
\text { Adalat Ghat, Old Palace, March } 2008\end{array}$ \\
\hline Family Pleidae: Paraplea spec. & Old Palace, aquatic plants, March 2008 \\
\hline Family Micronectidae: Micronecta spec. & Very common \\
\hline Family Corixidae: Sigara (Tropocorixa) spec. & Adalat Ghat, Old Palace, March 2008 \\
\hline Family Mesoveliidae: Mesovelia spec. & Old Palace, aquatic plants, March 2008 \\
\hline \multicolumn{2}{|c|}{ Order Coleoptera } \\
\hline Family Gyrinidae Gen spp. & Widespread and locally abundant \\
\hline Family Dytiscidae Gen spp. & Fairly common \\
\hline Family Hydrophilidae Gen spp. & Fairly common \\
\hline \multicolumn{2}{|c|}{ Total number of identified taxa: 30} \\
\hline
\end{tabular}

Table 4: Benthic Macro-Invertebrates of River Ganga main channel in comparison with lowland-reaches of large river systems (main channels) in Central Europe:

\begin{tabular}{|l|c|c|c|c|c|}
\multirow{2}{*}{\multicolumn{1}{c}{ Phylum / Class }} & $\begin{array}{c}\text { Subtropical River of } \\
\text { Oriental Region (India) }\end{array}$ & \multicolumn{3}{c|}{$\begin{array}{c}\text { Temperate Rivers of Palearctic Region } \\
\text { (Germany) }\end{array}$} \\
\cline { 2 - 6 } & Ganga & Oder & Rhein (a) & Rhein (b) & Main \\
\hline Porifera & - & - & 2 & 2 & 3 \\
\hline Bryozoa & 1 & 5 & 5 & 6 & - \\
\hline Hydrozoa & 1 & 2 & 2 & 2 & 1 \\
\hline Nemathelminthes & 1 & - & 4 & - & 1 \\
\hline Nemertini & 1 & - & 1 & - & - \\
\hline Turbellaria & - & 3 & 3 & 3 & 4 \\
\hline Gastropoda & 18 & 14 & 14 & 7 & 14 \\
\hline Bivalvia & 17 & 15 & 8 & 4 & 15 \\
\hline Polychaeta & 3 & - & - & - & 1 \\
\hline Oligochaeta & 14 & 28 & 6 & 4 & 5 \\
\hline Hirudinida & 9 & 9 & 7 & 6 & 14 \\
\hline Malacostraca & 8 & 7 & 7 & 7 & 10 \\
\hline Insecta & 22 & 37 & 19 & 12 & 52 \\
\hline Total number of identified taxa & 95 & 120 & 78 & 53 & 120 \\
\hline
\end{tabular}

River Ganga, Lower Gangetic Plain, Patna (India), altitude $\approx 53-55 \mathrm{~m}$ a.s.1.; Oder River (Schmid 1999), Lower Oder Valley (Germany), altitude $\approx 28-33 \mathrm{~m}$ a.s.1.; Rhein/Rhine (a) River (Ziese 1985, 1987), (a) Mainz - Wiesbaden (Germany), altitude $\approx 83 \mathrm{~m}$ a.s.1.; Rhein/Rhine (b) River (Sopp 1983), (b) Loreley - St. Goarshausen (Germany), altitude $\approx 75 \mathrm{~m}$ a.s.l.; Main River (Schleuter and Haybach 2003), Lower Main Plain (Germany), altitude $\approx 85-115 \mathrm{~m}$ a.s. $1 .$. 
Table 5: Physico-chemical parameters of River Ganga (India) compared with Oder, Rhine and Main Rivers (Germany)

\begin{tabular}{|l|c|c|c|c|}
\hline \multirow{2}{*}{ Parameters } & \multicolumn{4}{c|}{ Rivers } \\
\cline { 2 - 5 } & Ganga & Oder & Rhein (a) & Main \\
\hline Water Temperature $\left({ }^{\circ} \mathrm{C}\right)$ & $14.0-31.2$ & $0.0-26.7$ & -22.0 & -27.0 \\
\hline Conductivity $(\mu \mathrm{S} / \mathrm{cm})$ & $229-313$ & - & $475-850$ & $414-872$ \\
\hline $\mathrm{pH}$ & $8.3-8.7$ & $7.1-9.3$ & $7.3-9.0$ & - \\
\hline Dissolved Oxygen $(\mathrm{mg} / \mathrm{l})$ & $6.7-9.4$ & $3.3-15.7$ & $5.0-10.0$ & $5.45-13.35$ \\
\hline
\end{tabular}

Data sources: Ziese (1987), Sharma (1998), Trzebiatowski (1999), Bernerth et al. (2005), Brahmer \& Teichmann, (2008).

\section{Acknowledgements}

Support of K. Prasad (Patna University, India), is duly acknowledged. We are very much thankful to Lee Harding for reviewing the manuscript and Dilip K. Kedia, Ajit K. Singh Patna University) and Samir K. Sinha (WTI) for help during the field work and providing materials. Special thanks are due to Jean-Paul Trilles (Montpellier) and Andreas Allspach (Frankfurt) for identification of Isopoda, and Dirk Brandis (Kiel) for identification of Parathelphusidae. Thanks are also due to the Director (ZSI), Kolkata for the encouragements.

\section{Literature Cited}

Amoros, C. and A. L. Roux, 1988. Interactions between water-bodies within the floodplain of large rivers: function and development of connectivity. Proceedings of the 2nd International Seminar of "International Association of Landscape Ecology": 125-130.

Annandale, N., 1922. The Marine Element in the Fauna of the Ganges. Bijdragen tot de Dierkunde: 143-154.

Brahmer, G. and W. Teichmann, 2008. Ein Wärmesimulationsmodell für den hessischen Main. Jahresbericht 2007 des Hessischen Landesamtes für Umwelt und Geologie, Wiesbaden, 31-38.

Bernerth, H., W. Tobias and S. Stein, 2005. Faunenwandel im Main zwischen 1997 und 2002 am Beispiel des Makrozoobenthos, Faunistischökologische Untersuchungen des Forschungsinstitutes Senckenberg im hessischen Main. Hessisches Landesamt für Umwelt und Geologie, Wiesbaden, 1587.

Chapman, D., 1992. Water Quality Assessment. A guide to the use of biota, sediments and water in environmental monitoring, Chapman \& Hall, London: 585.

Datta Munshi, J. S., G. N. Singh and D. K. Singh, 1988. Ecology of Freshwater Polychaetes of River Ganga. Journal of Freshwater Biology, 1: 103-108.
Gates, G. E., 1972. Burmese Earthworms. Transactions of the American philosophical Society New Series, 62: 1-326.

Harding, W. A. and J. P. Moore, 1927. Hirudinea. The fauna of British India, including Ceylon and Burma. London, Taylor \& Francis: 302.

Illies, J., 1961. Versuch einer allgemeinen biozönotischen Gliederung der Fließgewässer. Internationale Revue der gesamten Hydrobiologie, 46: 205-213.

Illies, J. \& L. Botosaneanu, 1963. Problèmes et methods de la classification et de la zonation écologique des eaux courantes, considerées surtout du point de vue faunistique. Mitteilungen der internationalen Vereinigung für theoretische und angewandte Limnologie, 12: 1-57.

Kinzelbach, R., 1983. Zur Dynamik der ZoobenthonBiozönosen des Rheins. - Verhandlungen der Gesellschaft für Ökologie (Mainz 1981), Band 10: 263-271.

Kinzelbach, R. (Ed.), 1985. Die Tierwelt des Rheins einst und jetzt. Mainzer Naturwissenschaftliches Archiv, Beiheft 6: 85-103.

Mariappan, P., C. Balasundaram and J. -P. Trilles, 2003. Infection of Isopod Tachaea spongillicola on freshwater prawns Macrobrachium spp. in southern India. Diseases of Aquatic Organisms, 55: 259-260.

Mason, C. F., 1981. Biology of Freshwater Pollution. Longman, Harlow: 250.

Merritt, R. W. and K. W. Cummins, 1996. An Introduction to the Aquatic Insects of North America, Third Edition, Kendall/Hunt Publishing Company, Iowa: 862.

Nehring, S., 2003. Gebietsfremde Arten in deutschen Gewässern - ein Risiko für die Biodiversität. Schriftenreihe des BMVEL "Angewandte 
Wissenschaft" Heft 498 "Bedrohung der biologischen Vielfalt durch invasive gebietsfremde Arten: 40-52.

Nesemann, H., 2009. Aquatic Benthic Macroinvertebrate' Biological Diversity and their use in Habitat Quality Assessment at the Himalayan Hot Spots of River Ganga Basin. Thesis submitted in partial fulfillment of the requirements for the degree Doctor of Philosophy (Ph.D.). Submitted to the School of Science Kathmandu University (KU), Dhulikhel, Nepal: 212+50 Pls.

Nesemann, H., G. Sharma and R. K. Sinha, 2003. The Bivalvia species of the Ganga River and adjacent stagnant water bodies in Patna (Bihar, India) with special reference on Unionacea. Acta Conchyliorum, 7: 1-43.

Nesemann, H., G. Sharma and R. K. Sinha, 2004. Aquatic Annelida (Polychaeta, Oligochaeta, Hirudinea) of the Ganga River and adjacent water bodies in Patna (India: Bihar), with description of a new leech species (Family Salifidae). Annalen des Naturhistorischen Museums in Wien 105 B: 139-187.

Nesemann, H., S. Sharma, G. Sharma and R. K. Sinha, 2005. Illustrated Checklist of large Freshwater Bivalves of the Ganga River System (Mollusca: Bivalvia: Solecurtidae, Unionidae, Amblemidae). Nachrichtenblatt der Ersten Vorarlberger Malakologischen Gesellschaft, Rankweil, 13: 1-51,

Nesemann, H., S. Sharma, G. Sharma, S. N.Khanal, B. Pradhan, D. N. Shah and R. D. Tachamo, 2007. Aquatic Invertebrates of the Ganga River System: Volume 1 - Mollusca, Annelida, Crustacea (in part), Chandi Press: 263.

Obrdlik, P., G. Falkner and E. Castella, 1995. Biodiversity of Gastropoda in European floodplains. Archiv für Hydrobiologie, Suppl. 101, Large Rivers 9: 339-356.

Preston, H. B., 1915. Freshwater Gastropoda + Pelecypoda. The Fauna of British India including Ceylon and Burma. Francis \& Taylor, London: 244.

Roxburgh, W., 1801. An account of a new species of Delphinus and inhabitant of the Ganges. Asiatic Researches-Transactions of the Asiatic Society (Calcutta edition), 7: 170+5pls.

Schleuter, M. and A. Haybach, 2003. Das Makrozoobenthos des Mains in den Jahren 1992-2001 - Eine Artenliste. Lauterbornia, 48: 45-56.
Schmid, U., 1999. Das Makrozoobenthos des Unteren Odertales - Faunenzusammensetzung und Besiedlungsdynamik in einer Flußaue. Limnologie aktuell, 9: 317-336.

Sharan, R. K. and R. K. Sinha, 1988. Ganga Basin Research Project Buxar-Barh. Final Technical Report (July, 1985-June, 1988), Patna University, Patna. Ganga Project Directorate, New Delhi, Project No. J13013/24/83-En-I: 88.

Sharma, G., 1998. Ecological Study of Gangetic dolphin Platanista gangetica, Ph.D Patna University.

Sinha, R. K., 1988. Benthic Macroinvertebrates. In: Sharan, R. K. and R. K. Sinha: Ganga Basin Research Project Buxar-Barh. Final Technical Report (July, 1985-June, 1988), Patna University, Patna: 34$44+2 \mathrm{pls}$,

Sinha, R. K. and G. Sharma, 2001. The gastropod Stenothyra ornata Annandale and Prashad, 1921, A New Record from River Ganga in Bihar. Journal of the Bombay Natural History Society, 98 (3): 485-487.

Sinha, R. K., H. Nesemann and G. Sharma, 2003. New records of Physa (Gastropoda: Physidae) from Indian subcontinent. Club Conchylia Informationen, 34: 3-11.

Sinha, R. K., S. K.Sinha, G. Sharma and D. K. Kedia, 2010. Surfacing and diving behaviour of free-ranging River Ganga dolphin, Platanista gangetica gangetica. Current Science, 98: 230-236.

Smith, B. D. and G. T. Braulik. 2008. Platanista gangetica IUCN 2011. IUCN Red List of Threatened Species. Version 2011.1. www.iucnredlist.org Downloaded 12 July 2011.

Sopp, E., 1983. Verteilung des Makrozoobenthons im Querprofil des Rheins bei der Loreley. Verhandlungen der Gesellschaft für Ökologie (Mainz 1981) 10: 279285.

Stebbing, T. R. R., 1907. A Freshwater Isopod from Calcutta. Zoological Journal of the Linnéan Society (London) 30: 39-41, Plate 6.

Subba Rao N. V., 1989. Freshwater Molluscs of India. Calcutta: Zoological Survey of India: 289.

Tattersall, W. M., 1908. The fauna of the brackish ponds at Port Canning, Lower Bengal. Records of the Indian Museum 2: 233-239,Pls 21, 22. 
Trzebiatowski, R., 1999. Occurrence, catches and protection policies of Ichtyofauna in the Lower Oder Valley Landscape Park waters in relation to environmental conditions in 1982-1996, a review. Limnologie aktuell, 9: 387-406.

Vannote, R. L., G. W. Minshall, K. W. Cummins, J. R. Sedell and C. E. Cushing 1980: The River Continuum Concept. Canadian Journal of Fisheries and Aquatic Sciences, 37: 130-137.

Wiliams, D. D. and B. W. Feltmate, 1992. Aquatic Insects. C. A. B International, Melksham.

Ziese, M., 1985. Makrozoobenthon eines Querprofils des Rheins bei Wiesbaden. In: Kinzelbach, R. (Ed.). Die Tierwelt des Rheins einst und jetzt. Mainzer Naturwissenschaftliches Archiv, Beiheft, 6: 85-103.

Ziese, M., 1987. Das Makrozoobenthos des Rheins im Bereich von Mainz und Wiesbaden. Mainzer Naturwissenschaftliches Archiv, Beiheft, 7: 1-138. 